\title{
Information Communication Technology Use in Academic Libraries of Selected Tertiary Institutions in Ghana
}

\author{
Bernard Alando ${ }^{1}$, Francis Nashiru Ewuntomah ${ }^{2}$ \\ ${ }^{1}$ University for Development Studies \\ ${ }^{2}$ Northern Development Authority
}

\begin{abstract}
Academic libraries are critical contributors to knowledge generation which serve a wide spectrum of knowledge seekers. The shift from print to digital information has a high impact on all components of the academic library system. This study examined the factors affecting ICT usage by academic libraries in selected tertiary institutions in Ghana. A total of eight (8) tertiary institutions were selected for the study, with ninety-six (96) respondents made up of librarians, academic staff and students. Questionnaires were used to elicit the relevant data for the study. The data was analyzed using descriptive statistical analysis tools. The findings suggest that, there is a reasonable level of awareness among libraries of academic institutions about the potential benefits of ICT. Despite this, the current usage in most institutions was found to be unsophisticated. The study also identified budget constraints for ICT investment, inadequate commitment by management and erratic supply of electricity as major factors affecting usage. The study therefore concluded that more needs to be done in terms of policy commitment, training and upgrading of ICT infrastructure in order to improve the adoption and usage of ICT in academic libraries in Ghana.
\end{abstract}

Key words: Academic library, Information communication technology, ICT use in academic libraries, Information Management.

\section{INTRODUCTION}

$\mathrm{R}$ ecent advances in Information Communication Technology (ICT) have not only increased tremendously the ability to access, store and process information within the library system, but also have brought significant changes in the concept, organisation, functioning and management of library and information systems (Peyala, 2011). Libraries play a key role in promoting literacy by offering relevant and attractive reading material for all ages. The fundamental role of libraries include collection development, reference services management, document delivery service, access to organised collections and assistance of users in information search and retrieval (Husain \& Nazim, 2015; Cholin, 2005; Malhan, 2006).

With the onset of ICT, libraries now use various types of technologies to aid the services they render. Every day, new technological advancements affect the way information is handled in libraries and information centers. The impacts of new technologies are felt by libraries in every aspect.
Computing technology, communication technology and mass storage technology are some of the areas of continuous development that reshape the way that libraries access, retrieve, store, manipulate and disseminate information to users.

An academic library is a library that is attached to a higher education institution which serves two complementary purposes: to support the school's curriculum and to support the research of the university, faculty, and students (Susan C., \& Quinonez-Skinner J., 2009). Over the past twenty-seven years, academic libraries have been affected by the evolution of ICT, which is still accelerating.

ICT has impacted on every sphere of academic library activity especially in the form of the library collection development strategies, library building and consortia (Khan J., 2016). ICT presents an opportunity to provide value-added information services and access to a wide variety of digital based information resources to users. Furthermore, Stephen (2017) observed that academic libraries are also using modern ICT to automate their core functions, implement efficient and effective library cooperation and resource sharing networks; implement management information systems, develop institutional repositories of digital local contents, and digital libraries: and initiate ICT based capacity building programs for library users.

Hussaini S., Haruna M., \& Muhammad A., (2021), are also of the view that ICT has brought unprecedented transformation to academic library and information services, in terms of provision of conventional Library and Information Services (LIS) such as Electronic Online Public Access Catalogues (OPAC), reference services, bibliographic services, current awareness services, document delivery, inter-library loan, audio visual services and customer relations to provide more efficient and effective services. They offer convenient time, place, cost effective, faster and most-up-to-date dissemination and end user involvement in the library and information services process. The impact of ICT on information services is characterized by changes in format, content and method of production and delivery of information products. The emergence of the internet as the largest repository of information and knowledge has changed the role of libraries 
and information science professionals from intermediaries to facilitators; it has brought about new tools for dissemination of information and resulted in a shift from physical to virtual service environments and led to the extinction of some conventional information services and the emergence of new and innovational web-based ones.

Chalukya (2015) is of the opinion that the paradigm shift from the stand-alone libraries to library and information networks, available via the Internet, now provide end-users with a seamless connection to Internet-based services such as automated digital learning and research materials, multimedia and virtual access to a pool of resources across multiple databases online.

In spite of the enormous benefits that are derived from ICT in Academic Libraries globally, most academic libraries in Ghana continue to depend heavily on traditional library practices.

\section{Purpose of the Study}

The general purpose for this study is to assess the ICT use in academic libraries in selected tertiary institutions in Ghana. Specifically, the study intends to:

1. Find out the ICT hardware equipment being used in academic libraries in Ghana.

2. To examine the extent to which software tools are used to support academic library operations in Ghana.

3. Assess the challenges hindering the adoption of ICT resources in academic libraries in Ghana.

\section{Research Questions}

1. What type of ICT hardware equipment are used in academic libraries in Ghana?

2. What kinds of software tools are used to support academic library operations in Ghana?

3. What are the challenges hindering the adoption and usage of ICT resources in academic libraries in Ghana?

\section{REVIEW OF LITERATURE}

According to the Association of College and Research Libraries (2010), "Library systems at universities generally consist of a main university library plus several branches or special libraries. The large campus environment often defines the quality of the library in terms of the strengths and size of the research collection. The focus of the main and branch libraries is frequently on the needs of specific fields of study or departments and their research works.

According to Agyen-Gyasi et al., (2010) Academic libraries are essential contributors to knowledge generation and serve a wide spectrum of knowledge seekers. In fact, academic libraries have been described as the "heart" of the university, because they provide a place for students and faculty to do their research and advance their knowledge. A good library and information services have been noted as essential ingredient for research, and successful teaching and learning (Anyim, 2018).

\section{The Concept of ICT}

Information and Communications Technology (ICT) is a general term that stresses the role of unified communications and the integration of telecommunications (telephone lines and wireless signals), computers, middleware as well as necessary software, storage- and audio-visual systems, which enable users to create, access, store, transmit, and manipulate information (Tamilselvan N., Sivakumar N. \& Sevukan R., 2012). In other words, ICT consists of IT as well as telecommunication, broadcast media, all types of audio and video processing and transmission and network-based control and monitoring functions.

\section{Component of ICT}

Tamilselvan et al (2012) Further explains that the advancement in computer and telecommunication technologies is becoming a driving force in a modern-day society. Information and Communication Technology is a generic term used to describe a group of technologies. These technologies can be further grouped into three major components that include:

1. Computer Technology - The technologies that formed up the computer technology component include: workstations, mainframe computers, super computers, mini computers, artificial intelligence, microchip technology.

2. Communication Technology - the technologies that formed up communication technology include: audio technology, audio visual technology, motion picture, fax (facsimile transmission) etc.

3. Reproduction Technology - That include Reprographic, Micrographic and Printing Technologies.

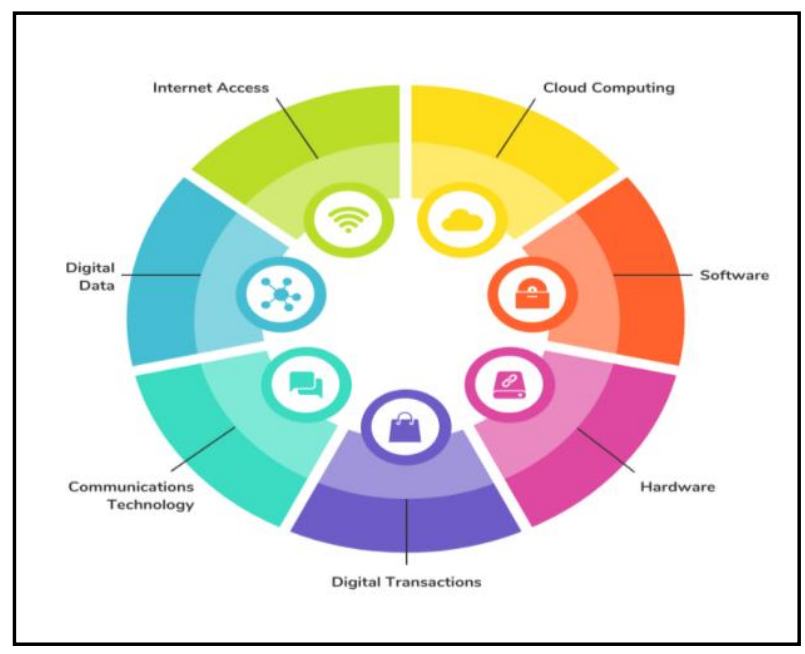

Components of ICT

Source: Observatory Systems (2019) 


\section{Use of ICT Software Resources in Academic Libraries}

It is now difficult to imagine a world without information technology. The provision and use of ICT is part and parcel of the entire system, to both the students, information professionals and the institutions. With the help of ICT to deliver the services of their user is very easy and fast and also it can save the time of user and staff both. Nowadays ICT has totally changed the concept of library and information center as it was in early days. Libraries are adopting ICT for performing both housekeeping operations as well as for providing services to the library patrons. Application of ICT has added value to the services and libraries are becoming popular among the patrons. With the aid of ICT libraries are actually marching towards achieving the goal of providing pinpointed exhaustive and expeditious information to those who are in need of that information.

According to Hussaini et al., (2021), advances in digital technologies and other ICT infrastructure, combined with a growing need for information have propelled the need for state-of-the-art library resources focused on ICT. The following are some of the state-of-the-art ICT library available in advance libraries:

1. Electronic Journals - newspapers, magazines, newsletters or other forms of electronic serial publications that are accessible over the internet, can be accessed using various technologies. Many publishers such as Emerald, Elsevier, Sage, Springer, EBSCO, J-Gate, John-Wiley are some of the publishers that include e-journals.

2. Document Scanning Services - Scanners are important equipment for library modernization. It is useful for scanning book pages with text, photograph and materials and offer tremendous support for the development of a digital and interactive/virtual library.

3. Electronic Document Delivery Service - Library used ICT based Inter-Library-Loan (ILL) to distribute copies of journal papers and other multimedia materials such as PDF (Portable Paper Format) to the desktop of the users. It helps the users to access information which is not available in their respective libraries.

4. Digital Library Service - Selections of digital sources of information are given by the digital library. It eliminates physical space, help user to remotely access information and also offers access to distributed information services. Its benefit is that it is capable of handling multilingual materials.

5. Institutional Repository Service - The institutional archive is a collection of resources provided by university to its community members for the control and dissemination by the institution and its community members of digital materials.

6. Audio-Visual Services - An important source of information, education and entertainment are the audio-visual materials. Many libraries hold audiovisual materials such as music, film, images and photographs etc. especially media libraries and large academic and public libraries.

7. Current Awareness Service (CAS) - Present knowledge program has become an essential way of keeping users in their fields of interest up to date. As basic as a copy of the table of content or a bulletin containing bibliographic documents, papers taken from current issues of journals and other information, and typically arranged by topics, the current knowledge service can be. Using a predefine search techniques, libraries now compile current knowledge bulletin and run on the database either on CD-ROM or online regularly to get the desired output. The production can also be stored on a local device and disseminated digitally (internet, intranet) and offline (print, CD-ROM, email) subject to copyright.

8. User Online Education - ICT especially the internet, are used by the libraries to introduce online-based bibliographic or library usage (library literacy) services targeted at their clients. These services include but are not limited to, online based tutorials, online resource searches and interactive tour of library collection, mostly accessible through intranets, extranet or the internet.

9. Online Chat Services - Every form of correspondence over the internet that allows an instantaneous delivery of text-based massage from sender to recipient can be responded to via online chat. It can be used for online reference resources and real-time advisory services in libraries. As well as point-to-point communications and multicast communications from one sender to multiple recipients, online chat with address both.

10. Reader Advisory and E-Reference Services - ICTs present libraries with an ability to provide reader advisory services and e-reference services with webbased copies. This includes resources such as reminding users about new releases or additions to the collection of libraries on the internet, Selective Distribution of Information (SDI) update and reader engagement facilities (virtual resource desk) etc. libraries are willing to assist their users through ICTbased consulting programs at academic institutions delivering classes through distance learning.

11. Electronic Theses and Dissertations (ETDs) - The provision of access to full-text copies of electronic theses and dissertations is linked to institutional repositories, especially in university libraries. It was difficult to view full text version of theses and dissertation from a distance area without ICT. Although theses and dissertation on microfiche and microfilm have been made available in developing countries, the only way to access these materials in Sub Saharan African has been by paying a visit to the libraries where the collections are stored. As a result, 
mostly closed collections of theses and dissertations in Africa have been accessed mostly by students and scholars living in the host world. This arrangement has been updated by ICTs. Projects aimed providing accesses to full-text of ETDs have been implemented in some university libraries in the SCANUL-ECS region, especially in the South Africa region, including the libraries in the following universities: MSUB, GU, HNGU etc.

12. Electronic Books Service - Materials, Software and Hardware Specification, Protocol, Digital Right Management, Connectivity, Archiving, Protection, Industry, Pricing and Features and the elements known to be imported for the use of e-books in an academic library.

13. Electronic Mail (E-mail) Service or Email Publishing - It is also possible to use this medium to send and receive emails with internet service. Email is very useful for transmitting messages to and from distant network-enhanced locations. In addition, it is helpful in different areas of the library system as well. It can also be claim that email may play an important role in information dissemination services. Email publishing is designed for the distribution of daily email messages based on quality. For readers, who love the convenience of delivering news stories, blogs and brief news newsletter on their email box, email publishing is a common alternative. To supplement their web and print services, newsletters are still commonly used by media organization.

14. Bulletin Board Service - An electronic messaging site that hosts posted messages and articles related to a popular topic or theme or interest is a bulletin board. It enables users to dial into their leaves messages or recover them. The messages can be addressed to all members of the bulletin board or to certain users only. Both messages will, however, be read by all users. For their web-based library facilities, many libraries used bulletin boards. As an open interface, the bulletin board framework is often used to invite feedback about a library's events or resources. A bulletin board system or BBS is a computer system that runs software that encourages people to use a terminal to connect and $\log$ in to the system. A user will perform functions such as uploading and installing applications and data once logged in, reading news and newsletters and sharing messages with other users, either via electronic mail or online messages boards, once logged in.

15. Internet Service - The information superhighway has become a centre for serious topics in the universe of science and has opened the floodgate for scholarly contact. The internet is a truncated form of internetworking, relating to the interconnection between two or more networks of computers. The internet is described as a network of computers and people worldwide. For global internet providers, it is an essential method. The advent of the internet has extremely high bandwidth, which, like never before, would broaden the potential for information collection and dissemination.

16. Web-based Online Public Access Catalogues (Web$O P A C)$ - The internet and web-based technology have allowed libraries to provide global access to their catalogues. It allows members of the library to view content from anywhere around the world while OPAC is accessible on the internet. It is also simpler for members of the library to understand and use OPAC from various library systems. The web-based OPAC enables other information services to be related, such as material tables, full text record, authors, title, publisher, year of publication etc.

17. Open-Source Software Service - Open-Source Software or OSS is a programming software that is publicly accessible, allowing the source code to be changed and the software to be adopted by and body and for any reason. We have seen the development of a range of ILS products in the open-source community in the last few years, such Integrated Library Systems (ILS) like: Koha, Digital Library Software like Greenstone, Digital Repository Software like DSpace, and Content Management Software such as module etc.

18. Ask-A-Librarian Service - Ask librarian services are internet-based questions and answers services that links customer to individuals with advanced topic information and skills in performing reliable searches. A web-based query entry form or an email address or both are available for most Ask-aLibrarian programs. Users are invited to use online form or via email address to send their questions. When a question is read by a service, it is delegated for addressing by an individual expert. A specialist responds with factual detail and or a list of data tools to the query. The answer is either sent to the email address of the user or is posted on the internet so that after a certain amount of time the user can view it. Oxford Collage Library, for example.

19. Library Network Service - The networks' essential function is to connect computers and other networking devises so that information can be transmitted immediately from one location to another. Networks allow many users to share and communicate with each other through common pathway. In library housekeeping and resource sharing, the networks include the Local Area Network (LAN) and Wide Area Network (WAN) serving a wide geographical area such as a nation or state, covering small geographical area such as a campus or building such as DELNET, ADINET, INDONET, INFLIBNET, MALIBNET, NICNET ADINET etc.

20. Reprographic and Micrographic Service - Such technologies are commonly used worldwide in 
libraries. Many research libraries have reprographic systems that have on-demand photocopies of every text. Microform is a common term for all information carriers who use microfilm or related optical media (including research) to capture and store high-density optically encoded data in the form of micro images, bit patterns or holograms of printed papers.

21. RFID Technology Service - RFID (Radio Frequency Identification) is a state-of-the-art device used to deter the stealing of library resources in modern libraries. Identification of radio frequencies is a term used for systems that use radio waves to automatically classify specific objects. It is the cheapest, simplest, most efficient way to map, find and handle library materials and is used in libraries in the circulation section and also in stock management for automated check-in and check-out services. It is an evolving technology for library automation and security that is more effective, simple and costefficient. Just like bar code, RFID is really similar. RFID technological advances continue to produce greater money capacities, broader ranges of reading and quick encoding.

22. Library Portal Service - A library portal is a singleentry point that incorporates the directory of subscribe library catalogues, electronic journals etc. The library portal serves the user's specific needs and the portal is also the standard platform for users to create library tools and facilities from a single point of entry and management. Librarians are becoming painfully conscious that is a challenge for end user to multiply electronic capital. It is a difficult for users to have the most convenient website or resource to scan for the information they need. The library gateway eliminates interface obstacles to remembering multiples log-in. Example, the library portal of Kashim Ibrahim Library (KIL).

\section{State and Characteristics of Academic libraries in Ghana}

The University of Ghana (UG), Legon, Kwame Nkrumah University of Science and Technology (KNUST), Kumasi, and the University of Cape Coast (UCC), Cape Coast, have been the three dominant state universities in Ghana. In 1992 the University for Development Studies (UDS), Tamale, and the University of Education of Winneba (UCEW), were added. Since then, other universities have started springing up. These Universities are known to have large libraries in Ghana. However, many of the libraries in these traditional public Universities are poorly resourced and lack up-to-date and relevant academic materials due to low funding. This state of affairs has carved a very low image for the libraries in the universities because they are not living up to expectation. Statements like "there's nothing in that library", "I go there to read my notes;" "Your books are too old;" "There are no books in my field"; and others are often expressed by clients and members of the university community. Lecturers tend to acquire the dominant text books in their subject areas in addition to one or two journals elsewhere and do not fancy the library much. References are easily made to university libraries of the developed countries; their rich stock (current and varied); prompt services; and modern equipment. Despite their importance, libraries tend to have a generally low image in Ghana, even in academic circles.

According to Gupta (2011), a university library is a library attached or associated with a university and used by students, teachers, researchers, administrative staff etc. of the university including the general public and the alumni and it is also known as the heart of the university. It works like the axis of all educational and research activities of all disciplines. According to Dr. Krishan Kumar (as cited in Gupta, 2011) "a university library is a part of a university set up, therefore, it exists to serve the objectives of its parent organization. Every library programme must support the university's total programme. In other words, a university library should aim to advance the functions of its university. It should reflect the character of the university". He also states that the major distinction between a college library and a university library is that a university library lays emphasis mainly upon research. Thus we find that research is a major objective of a university library. In other words, it circulates knowledge to generate new knowledge.

Much as libraries in Ghana can be blamed for poor image projection, much can be blamed on external factors such as inadequate funding and unfriendly university environments. University libraries in Ghana are poorly funded and regarded as a support and not the "heart" of the university.

\section{METHODOLOGY}

The descriptive research design was used in this study to observe the characteristics of academic libraries in the study area and to accurately, and systematically describe their extent of adoption of ICT tools in their operations.

Sample Size: A sample size of 108 respondents were obtained from a total of nine (9) tertiary institutions, made up of three (3) from the south and six (6) from north of the Ghana using convenient sampling technique. The nine selected institutions include University of Ghana Legon, Accra; Kwame Nkrumah University of Science and Technology, Kumasi; Kumasi Nursing and Midwifery Training College, Kumasi; from the south of Ghana and University for Development studies; Nursing and midwifery Training College Tamale; Tamale college of Education, Tamale; Bagabaga College of Education, Tamale; Tamale Polytechnic, Tamale; and Wa polytechnic, Wa.

Sampling Technic: The purposive sampling technique was employed to select twelve (12) respondents from each institution. The respondents were made up of one (1) library staff, one (1) ICT staff, two (2) academic staff, and eight (8) students from each of the institutions, yielding an overall sample size of 108 respondents. 
Questionnaire Administration: A Semi-structured selfadministered questionnaire, made up of both close and openended questions were used to capture data from the sampled units. A total of 96 questionnaire were returned, constituting a response rate of $88.8 \%$. Data was analyzed using the Statistical Package for Social Scientists (SPSS) version 24. The criteria for collecting data on factors hindering the adoption and use of ICT applications in libraries was based on a Likert scale as follows:

$$
\begin{array}{lll}
\text { 1. } & \text { Very highly computerized: } & 4.50 \leq \text { mean score } \leq 5.00 \\
\text { 2. } & \text { Highly computerized : } & 3.50 \leq \text { mean score } \leq 4.50 \\
\text { 3. } & \text { Moderately computerized : } & 2.50 \leq \text { mean score } \leq 3.50 \\
\text { 4. } & \text { Less computerized : } & 1.50 \leq \text { mean score } \leq 2.50 \\
\text { 5. } & \text { Not computerized : } & 1.00 \leq \text { mean score } \leq 1.50
\end{array}
$$

With ratings of 4 and 5 represented strong and very strong reasons respectively, therefore a factor was considered critical if it had a mean score of 3.0 or more. Where two or more criteria have the same mean score, the one with the lowest standard deviation was assigned the highest importance ranking (Field, 2005).

\section{IV. $\quad$ RESULTS AND DISCUSSIONS}

Out of one hundred and eight (108) questionnaires administered, a total of Ninety-six (96) were returned constituting a response rate of Eighty-eight-point eight percent $(88.8 \%)$. Table 1 below indicates the breakdown of the number of responses received from selected institutions: Sixty (60) completed questionnaires were received from the northern sector tertiary institutions constituted by University for Development studies, Tamale College of Education, Bagabaga College of Education, Tamale polytechnic, Wa polytechnic and Tamale Nursing and Midwifery training College and Thirty-six (36) questionnaires were received from the southern sector institutions which are the University of Ghana-Legon, Kwame Nkrumah University of Science and Technology and Kumasi Nursing and Midwifery Training College. These represent $88.3 \%$ and $100 \%$ response rates respectively. The overall response rate was about $89 \%$.

\section{Extent of adoption of ICT in Academic Libraries}

On the issue of respondents view point on the extent of current usage of ICT in their libraries (see Table.1), and $11.9 \%$ of the respondents were of the view that their current ICT usage is low, $44.1 \%$ thought the use of ICT is medium, $32.2 \%$ considered their ICT usage as high and $11.9 \%$ thought the extent of use of ICT is poor.
Table 1: Respondents views on extent of application of ICT in libraries.

\begin{tabular}{|c|c|c|c|c|c|}
\hline \multirow{2}{*}{$\begin{array}{c}\text { Institution's } \\
\text { Name }\end{array}$} & \multicolumn{5}{|c|}{ Extent of ICT Application in Selected Institution's } \\
\cline { 2 - 6 } & Poor & Low & Medium & High & $\begin{array}{c}\text { Not } \\
\text { sure }\end{array}$ \\
\hline KNUST & - & - & $\begin{array}{c}8 \\
(66.7 \%)\end{array}$ & $\begin{array}{c}4 \\
(33.3 \%)\end{array}$ & - \\
\hline UG-Legon & - & - & $\begin{array}{c}2 \\
(16.7 \%)\end{array}$ & $\begin{array}{c}10 \\
(83.3 \%)\end{array}$ & - \\
\hline $\begin{array}{c}\text { UDS-Wa } \\
\text { Campus }\end{array}$ & $\begin{array}{c}4 \\
(33.3 \%)\end{array}$ & $\begin{array}{c}2 \\
(16.7 \%)\end{array}$ & $6(50 \%)$ & & - \\
\hline KNMT C & $1(8.3 \%)$ & $2(16.7 \%)$ & $6(50 \%)$ & $3(25 \%)$ & - \\
\hline T NMTC & $1(33.3 \%)$ & $1(33.3 \%)$ & $1(33.3 \%)$ & - & - \\
\hline $\begin{array}{c}\text { Tamale } \\
\text { Polytechnic }\end{array}$ & - & $2(50 \%)$ & $1(25 \%)$ & $1(25 \%)$ & - \\
\hline $\begin{array}{c}\text { Wa } \\
\text { Polytechnic }\end{array}$ & - & - & $1(50 \%)$ & $1(50 \%)$ & - \\
\hline TACE & $1(50 \%)$ & - & $1(50 \%)$ & & - \\
\hline Total & 7 & 7 & 26 & 19 & - \\
\hline
\end{tabular}

Source: Field Survey

\section{Available ICT hardware infrastructure in Academic} Libraries

This part examined the availability and types of computers in use and communication hardware including operating systems used by the libraries. Respondents were asked which sort of ICT devices were in use in their libraries from a specific range. With reference to Table $4.5 \mathrm{a}, 39.6 \%$ of the respondents said their libraries used Desktop computers and $25.7 \%$ said they used laptops. Mobile ICT device such as Tablets were used in the libraries, according to $17.4 \%$ of the respondents. Multimedia projectors were also identified as ICT hardware used in the libraries (2.08\% of respondents). Respondents $(11.8 \%)$ also stated the following ICT devices (scanners, printers, photocopiers and routers) as being used in their libraries. The results from the study indicate that multimedia projectors $(2.08 \%)$ seem not to be often used in the academic libraries in studied because they are used in conference rooms in libraries for group discussions and presentations. Table $4.5 \mathrm{~b}$ further breaks down the use of hardware's at the institutional level.

Table 2: Types of hardware in use (a)

\begin{tabular}{|c|c|c|}
\hline \multirow{2}{*}{ ICT Device } & \multicolumn{2}{|c|}{ Responses } \\
\cline { 2 - 3 } & $\mathrm{N}$ & Proportion \\
\hline Desktop computers & 57 & 0.395 \\
\hline Laptops & 37 & 0.256 \\
\hline Tablet & 25 & 0.174 \\
\hline Multimedia projector & 3 & 0.0208 \\
\hline Others & 22 & 0.152 \\
\hline TOTAL & 144 & 1 \\
\hline
\end{tabular}

Source: Field Survey 
Types of Hardware in Use

Results from Table 3: indicate the use of hardware in institutional libraries. With respect to the usage of desktop computers the results indicates a high percentage of 80 for UDS - Wa Campus, Wa Poly recorded the least (28\%) usage of desktop computers.

Table 3: Types of hardware in use

\begin{tabular}{|l|r|r|r|r|r|r|}
\hline \multicolumn{1}{|c|}{ Institution's Name } & \multicolumn{1}{c|}{$\begin{array}{c}\text { Desktop } \\
\text { computers }\end{array}$} & \multicolumn{1}{c|}{ Laptop } & \multicolumn{1}{c|}{ Tablet } & Projectors & others & Total \\
\hline KNUST & $0.4(40 \%)$ & $0.2(20 \%)$ & $0.2(20 \%)$ & - & $0.2(20 \%)$ & 1 \\
\hline UG- LEGON & $0.273(27.3 \%)$ & $0.25(25 \%)$ & $0.295(29.5 \%)$ & $0.068(6.8 \%)$ & $0.114(11.4 \%)$ & 1 \\
\hline UDS-WA CAMPUS & $0.8(80 \%)$ & $0.2(20 \%)$ & - & - & - & 1 \\
\hline KNMTC & $0.33(33.3 \%)$ & $0.33(33.3 \%)$ & $0.03(3.3 \%)$ & - & $0.297(29.7 \%)$ & 1 \\
\hline TNMTC & $0.6(60 \%)$ & $0.2(20 \%)$ & $0.2(20 \%)$ & - & - & 1 \\
\hline $\begin{array}{l}\text { TAMALE } \\
\text { POLYTECHNIC }\end{array}$ & $0.44(44.4 \%)$ & $0.44(44.4 \%)$ & $0.111(11.1 \%)$ & - & 1 \\
\hline WA POLYTECHNIC & $0.25(25 \%)$ & $0.125(12.5 \%)$ & $0.375(37.5 \%)$ & - & $0.25(25 \%)$ & 1 \\
\hline TACE & $0.66(66.3 \%)$ & $0.33(33.3 \%)$ & & - & - & 1 \\
\hline
\end{tabular}

Source: Field Survey

Laptop computers were averagely used in libraries from institutions with Tamale Poly (44.4\%) having the highest usage while Wa poly had the least $(12.5 \%)$ usage. Wa poly had the highest $(37.5 \%)$ use of tablets followed by U.G $(29.5 \%)$ with KNMTC as the least users with a percentage of 3.3. With the use of Others (Scanners, photocopiers, printers etc.) KNMTC had the highest $(29.7 \%)$ use, followed by Wa poly $(25 \%)$ and KNUST (20\%) with U.G with the least $(11.4 \%)$ usage. University of Ghana was the only institution that indicated they use projectors in their library within their conference rooms for group discussions and presentations. Due to the fact that the results were exclusively calculated from multiple response question, high percentages might not necessarily mean higher use of hardware since some of the respondents selected fewer hardware devices as compared to others.

From the responses (see Table 2) it is inferred that the most common windows operating systems in use in the libraries are windows 7, windows 8 and windows 8.1. Majority (27.6\%) of the respondents indicated that most of the system software in use in the libraries was windows $7 ; 23.6 \%$ and $19.7 \%$ respectively indicated windows 8 and 8.1 were in use whiles $17.1 \%$ and $11.8 \%$ respectively said that Windows XP and Windows Vista were in use. This clearly demonstrates a shift from windows XP and Vista to Windows 7, 8 and 8.1 which are the most popular operating systems currently in use globally.

\section{Communication and Network Platform}

The availability of network platforms in the libraries for electronic communication within the academic institutions especially was another matter of interest in the study. It was found that, generally, there was a high level of computer network in place within the libraries as portrayed in Table 4. $66.1 \%$ of respondents agreed that their institutional libraries had their computers networked.
Table 4: Network of Computers in Libraries

\begin{tabular}{|c|c|c|c|c|}
\hline \multirow{2}{*}{$\begin{array}{c}\text { Institution's } \\
\text { Name }\end{array}$} & \multicolumn{2}{|c|}{$\begin{array}{c}\text { Are computers in your } \\
\text { library networked }\end{array}$} & \multicolumn{2}{c|}{ Networked Infrastructure } \\
\cline { 2 - 5 } & Yes & No & $\begin{array}{c}\text { Wide } \\
\text { Area } \\
\text { Network }\end{array}$ & $\begin{array}{c}\text { Local Area } \\
\text { Network }\end{array}$ \\
\hline KNUST & 12 & - & $5(41.7 \%)$ & $7(58.3 \%)$ \\
\hline UG LEGON & 12 & - & $1(8.3 \%)$ & $11(91.7 \%)$ \\
\hline UDS & & 12 & - & - \\
\hline KNMTC & 12 & - & $6(50 \%)$ & $6(50 \%)$ \\
\hline TNMTC & 1 & 2 & & $1(100 \%)$ \\
\hline TAMALE & - & 4 & - & - \\
\hline POLYTECHNIC & 1 & 1 & - & $1(100)$ \\
\hline POLYTECHNIC & 1 & 1 & - & $1(100)$ \\
\hline TACE & $39(66 \%)$ & $20(33.9)$ & $12(30.8 \%)$ & $27(69.2 \%)$ \\
\hline TOTAL & & & &
\end{tabular}

Source: Field Survey

With regards to the types of network infrastructure used by the libraries, the study found that $69.2 \%$ of the respondents agreed that their libraries used Local Area Network (LAN), while $30.8 \%$ of them agreed that the libraries used Wide Area Network (WAN). In support of this finding, respondents from UG, KNUST and KNMTC indicated they had access to this facility at the time of visit.

The use of emails and access to internet in libraries was found to be generally high. The use of emails and internet characterizes the basic technologies required for accessing the World Wide Web and electronic communications within the academic community. The study discovered that email usage for official communication by institutions was very high (agreed by $79.7 \%$ respondents), $20.3 \%$ of the respondents indicated they do not use emails for official communication. It was further revealed that access to internet facilities by libraries was very common (93.2\% of respondents agreed). 
Table 5: Access to Internet

\begin{tabular}{|c|c|c|c|c|c|c|c|}
\hline \multirow{2}{*}{ Institution's Name } & \multicolumn{2}{|c|}{ Access to internet } & \multicolumn{2}{|c|}{$\%$} & \multicolumn{2}{c|}{ Where internet is accessed in your library } \\
\cline { 2 - 8 } & Yes & No & Yes & No & $\begin{array}{c}\text { Librarians } \\
\text { office only }\end{array}$ & $\begin{array}{c}\text { Within the } \\
\text { library }\end{array}$ & $\begin{array}{c}\text { Librarians } \\
\text { office } / \text { within } \\
\text { the library }\end{array}$ \\
\hline KNUST & 12 & - & 100 & - & - & $9(75 \%)$ & $3(25 \%)$ \\
\hline UG-LEGON & 12 & - & 100 & - & - & $4(33.3 \%)$ & $8(66.7 \%)$ \\
\hline UDS-WA CAMPUS & 12 & & 100 & - & $4(33.3 \%)$ & $7(58.3 \%)$ & $1(8.3 \%)$ \\
\hline KNMTC & 12 & - & 100 & - & $1(8.3 \%)$ & - & $11(91.7)$ \\
\hline TNMTC & 2 & 1 & 66.7 & 33.7 & - & $1(50 \%)$ & $1(50 \%)$ \\
\hline TAMALE POLYTECHNIC & 2 & 2 & 50 & 50 & $1(50 \%)$ & - & $1(50 \%)$ \\
\hline WA POLYTECHNIC & 1 & 1 & 50 & 50 & $1(100)$ & - & - \\
\hline TACE & 2 & - & 100 & - & - & $2(100 \%)$ & - \\
\hline TOTAL & 55 & 4 & 93.2 & 6.8 & $12.7 \%$ & $41.8 \%$ & $45.5 \%$ \\
\hline
\end{tabular}

Source: Field Survey

Regarding where internet can be accessed in the library, $10 \%$ of the respondents indicated that access was only available at the librarian's office, $43.6 \%$ stated they could have access to internet within the library itself, $45.5 \%$ indicated they could have access to both at the library and within librarians office . On issues of institutions having a page on the World Wide Web (WWW), the study found that all of the institutions have a web address (100\% responses) for its internal and external links with the rest of the global world. From the above statistics, it can be concluded that the libraries internet infrastructure, though has an averagely network system, the use of the internet and email for its official communication with the academic community appears to be high.

The study also found that access to electronic library services within the libraries was quite low (i.e. $44.1 \%$ of responses) Majority of the respondents (about 55.9\%) observed that their libraries do not provide electronic library services. The few respondents $(44.1 \%)$ who indicated that their libraries had access to electronic library services indicated the following electronic library services as being offered by their libraries:

- Information about the library

- Update of users of available or new documents

- Access to academic resources e.g. journals and repositories

- Research repositories

- Access to Online Public Access Catalogue (OPAC)

- Access to subscribed academic database

- Ability to search all online research materials of the university

- Online book search

- Chat services, electronic journals, e-books, articles

- Off-campus access to library services

The study discovered that in the few libraries which provide e-library service, they are usually accessed by users with the aid of the web addressor and is usually updated by the repository team and the electronic support unit and this is done regularly after going through processes. The e-library service is usually accessed by the entire academic community which provides the service in their libraries.

\section{Analysis of Available ICT software tools}

This section analyzed the level of computerization of the libraries' activities/operations and the extent of use of some advanced ICT applications and tools to improve the performance of libraries in tertiary institutions in Ghana. The mean index score statistical analysis will be employed in this section.

For the determination of the degree of use of ICT applications in libraries operations, the following classifications or ratings based on the likert scale was used (Majid, 1997; Aminudin, 2006) which are:

a. Very highly computerized: $4.50 \leq$ mean score $\leq 5.00$

b. Highly computerized: $3.50 \leq$ mean score $\leq 4.50$

c. Moderately computerized $2.50 \leq$ mean score $\leq 3.50$

d. Less computerized: $1.50 \leq$ mean score $\leq 2.50$

e. Not computerized $1.00 \leq$ mean score $\leq 1.50$

\section{Activities Computerized in the Library}

The Tables (5, 6 and 7) below indicates the activities which are computerized in the libraries and the mean score of their computerization. Mean ratings were calculated on a scale ranging from 1-4 (1 = "Never",2 =Occasionally, 3= Quiet Often, 4 = "Always").

From the selected university category institutions (see Table 5), the results indicates that University of Ghana had an average mean score of 3.09 with most of its library activities automated at a moderate level with activities such as Library Instructions (3.75), Online Database Searching (3.67), Downloading and Uploading (3.50), Word Processing/Mailing (3.50), Public Access/Computer Literacy (3.50), Reservations (3.50) and Online Catalogue (3.50) as activities Highly Computerized. Respondents also indicated their library did 
not practice inter library loan with the assistant librarian indicating it was expensive to practice.

Respondent from the library of Kwame Nkrumah University of Science and Technology rated eleven (11) of their library activities as less computerized with the rest of their library activities as moderately computerized while acquisition/accession list was ranked the least activity computerized in their library.

University for Development Studies - Wa campus which is the youngest among the selected universities, respondents indicated their library activities were not automated with an average mean score of 1.00 .

\section{Activities Computerized in Selected Universities}

Activities such as Bibliographic listings, Statistics/report, scheduling/Planning, Issuing, Retrospective Conversion, and Catalogue/Label Production were moderately computerized activities in both University of Ghana and Kwame Nkrumah University of Science and Technology. The results also show that University of Ghana's library from the university category is the only library that has its library activities highly computerized.

Table 6: Activities Computerized in Selected Universities

\begin{tabular}{|c|c|c|c|c|c|c|c|c|c|}
\hline \multirow{2}{*}{ Activity } & \multicolumn{3}{|c|}{ KNUST } & \multicolumn{3}{|c|}{ UG-LEGON } & \multicolumn{3}{|c|}{ UDS } \\
\hline & $\mathrm{N}$ & Mean & SD & $\mathrm{N}$ & mean & SD & $\mathrm{N}$ & mean & SD \\
\hline Acquisition/Accession list & 12 & 1.83 & 1.337 & 12 & 3.42 & 1.832 & 12 & 1.00 & 0.00 \\
\hline Order file/report & 12 & 2.00 & 1.044 & 12 & 2.92 & 1.881 & 12 & 1.00 & 0.00 \\
\hline $\begin{array}{l}\text { Serial check-in/out and } \\
\text { claiming }\end{array}$ & 12 & 1.92 & .793 & 12 & 3.08 & 1.782 & 12 & 1.00 & 0.00 \\
\hline Union/holding list & 12 & 2.33 & 1.231 & 12 & 2.75 & 1.815 & 12 & 1.00 & 0.00 \\
\hline $\begin{array}{c}\text { Catalogue card/label } \\
\text { production }\end{array}$ & 12 & 2.50 & 1.243 & 12 & 3.17 & 1.992 & 12 & 1.00 & 0.00 \\
\hline Retrospective conversion & 12 & 2.58 & 1.240 & 12 & 3.08 & 1.929 & 12 & 1.00 & 0.00 \\
\hline Online catalogue & 12 & 2.67 & 1.231 & 12 & 3.50 & 1.784 & 12 & 1.00 & 0.00 \\
\hline Issuing & 12 & 2.58 & 1.311 & 12 & 3.08 & 1.929 & 12 & 1.00 & 0.00 \\
\hline Inter library loan & 12 & 2.17 & 1.193 & 12 & 1.33 & 1.105 & 12 & 1.00 & 0.00 \\
\hline Reservations & 12 & 2.08 & 1.240 & 12 & 3.50 & 1.931 & 12 & 1.00 & 0.00 \\
\hline Over dues & 12 & 2.42 & 1.240 & 12 & 3.00 & 1.859 & 12 & 1.00 & 0.00 \\
\hline AV acquisition/ cataloguing & 12 & 2.58 & 1.379 & 12 & 2.08 & 1.782 & 12 & 1.00 & 0.00 \\
\hline Accounting/budgeting & 12 & 2.67 & 1.371 & 12 & 2.33 & 1.775 & 12 & 1.00 & 0.00 \\
\hline Word processing/mailing & 12 & 2.75 & 1.422 & 12 & 3.50 & 1.931 & 12 & 1.00 & 0.00 \\
\hline Scheduling/planning & 12 & 2.58 & 1.379 & 12 & 2.75 & 1.765 & 12 & 1.00 & 0.00 \\
\hline Statistics/report & 12 & 2.50 & 1.314 & 12 & 3.25 & 1.913 & 12 & 1.00 & 0.00 \\
\hline Database construction & 12 & 2.33 & 1.303 & 12 & 3.33 & 1.826 & 12 & 1.00 & 0.00 \\
\hline Online database searching & 12 & 2.33 & 1.155 & 12 & 3.67 & 1.723 & 12 & 1.00 & 0.00 \\
\hline Downloading/uploading & 12 & 2.42 & 1.240 & 12 & 3.50 & 1.784 & 12 & 1.00 & 0.00 \\
\hline Indexing and abstracting & 12 & 2.33 & 1.435 & 12 & 3.33 & 1.826 & 12 & 1.00 & 0.00 \\
\hline Bibliographic listings & 12 & 2.92 & 1.505 & 12 & 3.25 & 1.765 & 12 & 1.00 & 0.00 \\
\hline Library instruction & 12 & 2.92 & 1.505 & 12 & 3.75 & 1.603 & 12 & 1.00 & 0.00 \\
\hline $\begin{array}{c}\text { Public access/computer } \\
\text { literacy }\end{array}$ & 12 & 2.75 & 1.545 & 12 & 3.50 & 1.679 & 12 & 1.00 & 0.00 \\
\hline Average mean & \multicolumn{3}{|c|}{2.44} & \multicolumn{3}{|c|}{3.09} & \multicolumn{3}{|c|}{1.00} \\
\hline
\end{tabular}

It can be concluded from Table 6 that University of Ghana has its library activities automated than that of KNUST and UDS libraries, it further suggests that libraries of UG and KNUST will provide effective and efficient services as compared to UDS.

\section{Activities Computerized in Selected Colleges}

The results showed in Table 7 indicate that Tamale Nursing and Midwifery College and Tamale College of Education libraries were not automated with an average mean score of
1.03 and 1.36 respectively. Kumasi Nursing and Midwifery College had a mean score of 2.19 , with six of its library activities such as acquisition/accession, word processing/mailing, statistics/report, database construction, 
online database searching and indexing and abstracting as moderately computerized with a mean score between 2.50 and 3.50. Activities such as Inter library loan (1.00) and Over dues
(1.33) were not computerized in their libraries with the rest of the activities less computerized.

Table 7: Activities Computerized in Selected Colleges

\begin{tabular}{|c|c|c|c|c|c|c|c|c|c|}
\hline \multirow{2}{*}{ Activity } & \multicolumn{3}{|c|}{ KNMTC } & \multicolumn{3}{|c|}{ TNMTC } & \multicolumn{3}{|c|}{ TACE } \\
\hline & $\mathrm{N}$ & Mean & SD & $\mathrm{N}$ & Mean & SD & $\mathrm{N}$ & Mean & SD \\
\hline Acquisition/Accession list & 12 & 2.80 & 1.279 & 3 & 1.00 & 0.00 & 2 & 1.50 & .707 \\
\hline Order file/report & 12 & 2.17 & 1.267 & 3 & 1.00 & 0.00 & 2 & 1.50 & .707 \\
\hline Serial check-in/out and claiming & 12 & 1.83 & 1.267 & 3 & 1.00 & 0.00 & 2 & 1.50 & .707 \\
\hline Union/holding list & 12 & 1.58 & .900 & 3 & 1.00 & 0.00 & 2 & 1.50 & .707 \\
\hline Catalogue card/label production & 12 & 2.42 & 1.379 & 3 & 1.00 & 0.00 & 2 & 1.50 & .707 \\
\hline Retrospective conversion & 12 & 1.75 & 1.138 & 3 & 1.00 & 0.00 & 2 & 1.50 & .707 \\
\hline Online catalogue & 12 & 2.42 & 1.379 & 3 & 1.00 & 0.00 & 2 & 1.50 & .707 \\
\hline Issuing & 12 & 1.92 & 1.165 & 3 & 1.00 & 0.00 & 2 & 1.50 & .707 \\
\hline Inter library loan & 12 & 1.00 & .000 & 3 & 1.00 & 0.00 & 2 & 1.50 & .707 \\
\hline Reservations & 12 & 1.92 & 1.084 & 3 & 1.00 & 0.00 & 2 & 1.50 & .707 \\
\hline Over dues & 12 & 1.33 & .492 & 3 & 1.00 & 0.00 & 2 & 1.50 & .707 \\
\hline AV acquisition/ cataloguing & 12 & 2.33 & 1.371 & 3 & 1.00 & 0.00 & 2 & 1.50 & .707 \\
\hline Accounting/budgeting & 12 & 2.42 & 1.311 & 3 & 1.00 & 0.00 & 2 & 1.50 & .707 \\
\hline Word processing/mailing & 12 & 2.67 & 1.497 & 3 & 1.00 & 0.00 & 2 & 1.50 & .707 \\
\hline Scheduling/planning & 12 & 2.42 & 1.311 & 3 & 1.00 & 0.00 & 2 & 1.50 & .707 \\
\hline Statistics/report & 12 & 2.92 & 1.782 & 3 & 1.00 & 0.00 & 2 & 1.50 & .707 \\
\hline Database construction & 12 & 2.58 & 1.505 & 3 & 1.00 & 0.00 & 2 & 1.50 & .707 \\
\hline Online database searching & 12 & 2.83 & 1.528 & 3 & 1.00 & 0.00 & 2 & 1.50 & .707 \\
\hline Downloading/uploading & 12 & 2.42 & 1.505 & 3 & 1.00 & 0.00 & 2 & 1.50 & .707 \\
\hline Indexing and abstracting & 12 & 2.50 & 1.446 & 3 & 1.00 & 0.00 & 2 & 1.50 & .707 \\
\hline Bibliographic listings & 12 & 2.33 & 1.231 & 3 & 1.00 & 0.00 & 2 & 1.50 & .707 \\
\hline Library instruction & 12 & 2.33 & 1.371 & 3 & 1.00 & 0.00 & 2 & 1.50 & .707 \\
\hline Public access/computer literacy & 12 & 2.33 & 1.435 & 3 & 1.00 & 0.00 & 2 & 1.50 & .707 \\
\hline Average mean & \multicolumn{3}{|c|}{2.19} & \multicolumn{3}{|c|}{1.03} & \multicolumn{3}{|c|}{1.36} \\
\hline
\end{tabular}

Source: Field Survey

It can be concluded from the sampled colleges that Kumasi Nursing and Midwifery library is relatively automated as compared to Tamale Nursing and Midwifery College and Tamale College of Education whose libraries are not automated.

The results (See Table 8) below shows that Tamale Polytechnic and Wa Polytechnic libraries are both not automated with an average mean score of 1.03.

Table 8: Activities Computerized in selected Polytechnics

\begin{tabular}{|c|c|c|c|c|c|c|}
\hline \multirow{2}{*}{ Activity } & \multicolumn{3}{|c|}{$\begin{array}{c}\text { Tamale } \\
\text { Polytechnic }\end{array}$} & \multicolumn{3}{c|}{ Wa Polytechnic } \\
\cline { 2 - 7 } & $\mathrm{N}$ & $\begin{array}{c}\text { Mea } \\
\mathrm{n}\end{array}$ & $\mathrm{SD}$ & $\mathrm{N}$ & $\begin{array}{c}\text { Mea } \\
\mathrm{n}\end{array}$ & $\mathrm{SD}$ \\
\hline Acquisition/Accession list & 4 & 1.00 & .000 & 2 & 1.00 & 0.00 \\
\hline Order file/report & 4 & 1.00 & .000 & 2 & 1.00 & 0.00 \\
\hline
\end{tabular}

\begin{tabular}{|c|c|c|c|c|c|c|}
\hline $\begin{array}{c}\text { Serial check-in/out and } \\
\text { claiming }\end{array}$ & 4 & 1.00 & .000 & 2 & 1.00 & 0.00 \\
\hline Union/holding list & 4 & 1.00 & .000 & 2 & 1.00 & 0.00 \\
\hline $\begin{array}{c}\text { Catalogue card/label } \\
\text { production }\end{array}$ & 4 & 1.00 & .000 & 2 & 1.00 & 0.00 \\
\hline Retrospective conversion & 4 & 1.00 & .000 & 2 & 1.00 & 0.00 \\
\hline Online catalogue & 4 & 1.00 & .000 & 2 & 1.00 & 0.00 \\
\hline Issuing & 4 & 1.00 & .000 & 2 & 1.00 & 0.00 \\
\hline Inter library loan & 4 & 1.00 & .000 & 2 & 1.00 & 0.00 \\
\hline Reservations & 4 & 1.00 & .000 & 2 & 1.00 & 0.00 \\
\hline Over dues & 4 & 1.00 & .000 & 2 & 1.00 & 0.00 \\
\hline $\begin{array}{c}\text { AV acquisition/ } \\
\text { cataloguing }\end{array}$ & 4 & 1.00 & .000 & 2 & 1.00 & 0.00 \\
\hline Accounting/budgeting & 4 & 1.00 & .000 & 2 & 1.00 & 0.00 \\
\hline Word processing/mailing & 4 & 1.00 & .000 & 2 & 1.00 & 0.00 \\
\hline
\end{tabular}




\begin{tabular}{|c|c|c|c|c|c|c|}
\hline Scheduling/planning & 4 & 1.00 & .000 & 2 & 1.00 & 0.00 \\
\hline Statistics/report & 4 & 1.00 & .000 & 2 & 1.00 & 0.00 \\
\hline Database construction & 4 & 1.00 & .000 & 2 & 1.00 & 0.00 \\
\hline Online database searching & 4 & 1.00 & .000 & 2 & 1.00 & 0.00 \\
\hline Downloading/uploading & 4 & 1.00 & .000 & 2 & 1.00 & 0.00 \\
\hline Indexing and abstracting & 4 & 1.00 & .000 & 2 & 1.00 & 0.00 \\
\hline Bibliographic listings & 4 & 1.00 & .000 & 2 & 1.00 & 0.00 \\
\hline Library instruction & 4 & 1.00 & .000 & 2 & 1.00 & 0.00 \\
\hline $\begin{array}{c}\text { Public access/computer } \\
\text { literacy }\end{array}$ & 4 & 1.00 & .000 & 2 & 1.00 & 0.00 \\
\hline Average mean & \multicolumn{7}{|c|}{1.03} & \multicolumn{5}{|c}{1.03} \\
\hline
\end{tabular}

Source: Field Survey

\section{Challenges hindering the adoption and usage of ICT resources Universities in Ghana}

Results from Table 8 shows that High cost of employing ICT professionals in their library was ranked as the factor that hinder the use of ICT in KNUST library, while Budget constraints for ICT investment, Inadequate commitment by tertiary institutions management towards ICT and Erratic supply of electricity were ranked as the major factors that hinder the use of ICT in academic libraries under the University category by respondents of University of Ghana and University for Development Studies . Majority of the client not interested in the library ICT base was ranked as the least factor that hinder ICT use in KNUST and UG while UDS ranked fear of job losses/making professionals redundant as the least factor.

Table 9: Challenges hindering the adoption and use of ICT resources in academic libraries in Ghana

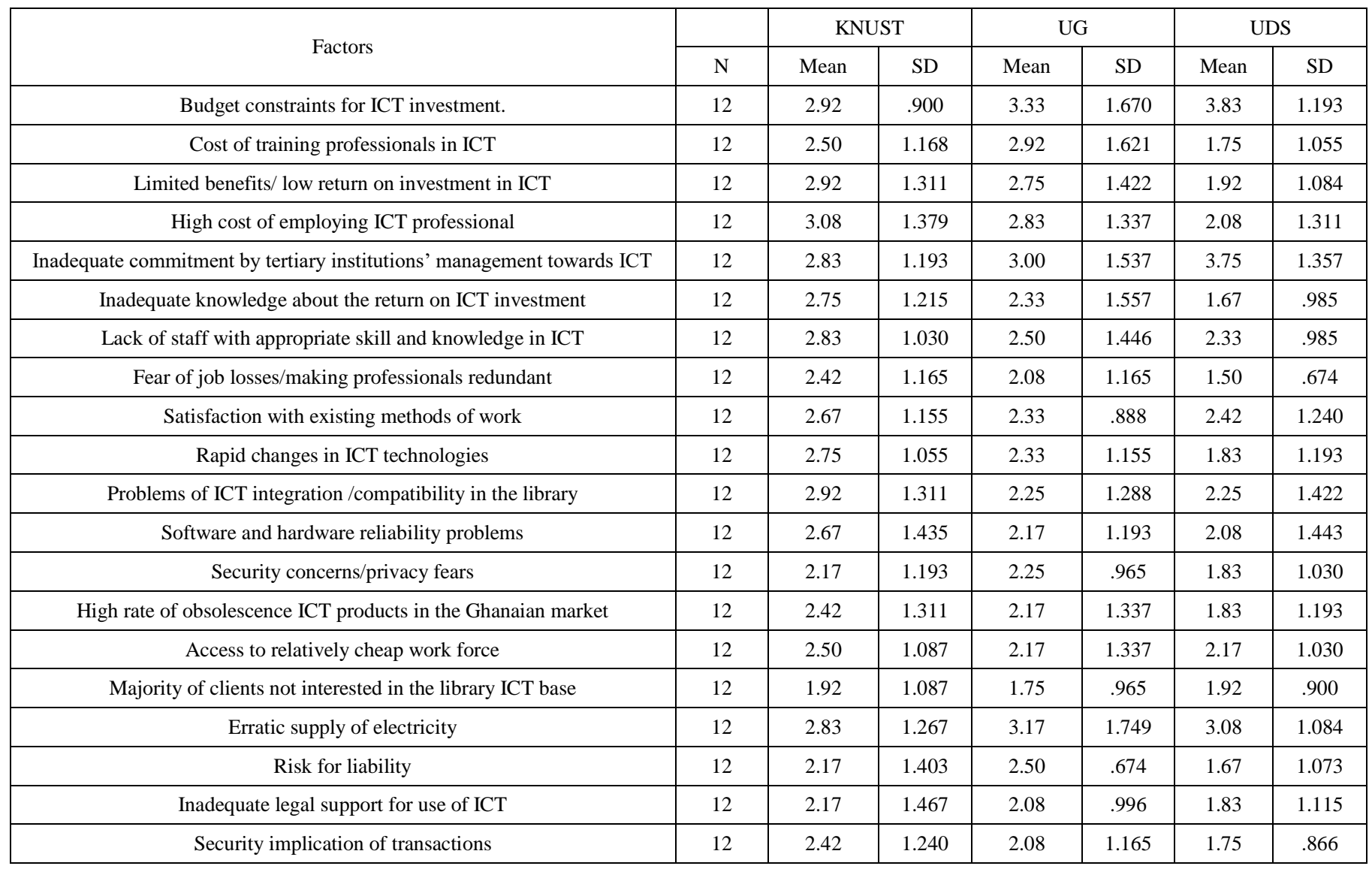

Source: Field Survey

\section{Factors hindering the adoption and use of ICT in Colleges}

Respondents from the college category identified (See Table 9) Inadequate commitment by tertiary institutions management towards ICT, Satisfaction with existing methods of work, Problems of ICT integration/compatibility in the library, High rate of obsolescence of ICT products in Ghanaian market, Erratic supply of electricity, Budget constraints for ICT investment, Lack of staff with appropriate skills and knowledge in ICT and Rapid changes in ICT technologies as factors affecting the adoption and use of ICT. The respondents from KNMTC also ranked Software and hardware reliability problems and rapid changes in technologies as the least factors hindering ICT use, Security 
concerns/privacy issues and rapid changes in technologies were identified by TNMTC while TACE identified Security implications of transactions as the least factor hindering the use of ICT in their library.

Table 10: Challenges hindering the adoption and usage of ICT resources by Colleges in Ghana

\begin{tabular}{|c|c|c|c|c|c|c|c|}
\hline \multirow[b]{2}{*}{ Factors } & \multirow[b]{2}{*}{$\mathrm{N}$} & \multicolumn{2}{|c|}{ KNMTC } & \multicolumn{2}{|c|}{ TNMTC } & \multicolumn{2}{|c|}{ TACE } \\
\hline & & $\begin{array}{c}\mathrm{Me} \\
\text { an }\end{array}$ & SD & $\begin{array}{c}\mathrm{Me} \\
\text { an }\end{array}$ & SD & $\begin{array}{c}\text { Mea } \\
\mathrm{n}\end{array}$ & $\mathrm{SD}$ \\
\hline $\begin{array}{l}\text { Budget constraints for } \\
\text { ICT investment. }\end{array}$ & 12 & $\begin{array}{c}2.7 \\
5\end{array}$ & $\begin{array}{c}1.21 \\
5\end{array}$ & $\begin{array}{c}3.6 \\
7\end{array}$ & $\begin{array}{c}1.15 \\
5\end{array}$ & 3.33 & 1.557 \\
\hline $\begin{array}{l}\text { Cost of training } \\
\text { professionals in ICT }\end{array}$ & 12 & $\begin{array}{c}2.7 \\
5\end{array}$ & $\begin{array}{c}1.13 \\
8\end{array}$ & $\begin{array}{c}2.4 \\
2\end{array}$ & .996 & 2.83 & .718 \\
\hline $\begin{array}{l}\text { Limited benefits/ low } \\
\text { return on investment in } \\
\text { ICT }\end{array}$ & 12 & $\begin{array}{c}2.5 \\
8\end{array}$ & $\begin{array}{c}1.16 \\
5\end{array}$ & $\begin{array}{c}2.2 \\
5\end{array}$ & $\begin{array}{c}1.21 \\
5\end{array}$ & 1.67 & .888 \\
\hline $\begin{array}{l}\text { High cost of } \\
\text { employing ICT } \\
\text { professional }\end{array}$ & 12 & $\begin{array}{c}2.7 \\
5\end{array}$ & $\begin{array}{c}1.05 \\
5\end{array}$ & $\begin{array}{c}2.5 \\
0\end{array}$ & $\begin{array}{c}1.31 \\
4\end{array}$ & 2.33 & 1.155 \\
\hline $\begin{array}{c}\text { Inadequate } \\
\text { commitment by } \\
\text { tertiary institutions' } \\
\text { management towards } \\
\text { ICT } \\
\end{array}$ & 12 & $\begin{array}{c}3.1 \\
7\end{array}$ & $\begin{array}{c}1.33 \\
7\end{array}$ & $\begin{array}{c}3.6 \\
7\end{array}$ & $\begin{array}{c}1.30 \\
3\end{array}$ & 3.25 & 1.288 \\
\hline $\begin{array}{l}\text { Inadequate knowledge } \\
\text { about the return on } \\
\text { ICT investment }\end{array}$ & 12 & $\begin{array}{c}2.8 \\
3\end{array}$ & $\begin{array}{c}1.11 \\
5\end{array}$ & $\begin{array}{c}2.8 \\
3\end{array}$ & $\begin{array}{c}1.26 \\
7\end{array}$ & 2.50 & 1.243 \\
\hline $\begin{array}{l}\text { Lack of staff with } \\
\text { appropriate skill and } \\
\text { knowledge in ICT }\end{array}$ & 12 & $\begin{array}{c}2.5 \\
8\end{array}$ & $\begin{array}{c}1.24 \\
0\end{array}$ & $\begin{array}{c}3.1 \\
7\end{array}$ & $\begin{array}{c}1.03 \\
0\end{array}$ & 2.08 & 1.379 \\
\hline $\begin{array}{l}\text { Fear of job } \\
\text { losses/making } \\
\text { professionals } \\
\text { redundant }\end{array}$ & 12 & $\begin{array}{c}2.5 \\
0\end{array}$ & .905 & $\begin{array}{c}2.2 \\
5\end{array}$ & $\begin{array}{c}1.13 \\
8\end{array}$ & 1.67 & .651 \\
\hline $\begin{array}{l}\text { Satisfaction with } \\
\text { existing methods of } \\
\text { work }\end{array}$ & 12 & $\begin{array}{c}3.0 \\
8\end{array}$ & .900 & $\begin{array}{c}3.0 \\
0\end{array}$ & .739 & 2.67 & 1.303 \\
\hline $\begin{array}{c}\text { Rapid changes in ICT } \\
\text { technologies }\end{array}$ & 12 & $\begin{array}{c}2.3 \\
3 \\
\end{array}$ & $\begin{array}{c}1.23 \\
1\end{array}$ & $\begin{array}{c}1.6 \\
7\end{array}$ & .778 & 3.08 & .996 \\
\hline $\begin{array}{c}\text { Problems of ICT } \\
\text { integration } \\
\text { /compatibility in the } \\
\text { library } \\
\end{array}$ & 12 & $\begin{array}{c}3.0 \\
8\end{array}$ & $\begin{array}{c}1.37 \\
9\end{array}$ & $\begin{array}{c}1.8 \\
3\end{array}$ & .937 & 2.58 & 1.505 \\
\hline $\begin{array}{l}\text { Software and hardware } \\
\text { reliability problems }\end{array}$ & 12 & $\begin{array}{c}2.3 \\
3 \\
\end{array}$ & .985 & $\begin{array}{c}1.7 \\
5\end{array}$ & .622 & 2.25 & 1.422 \\
\hline $\begin{array}{c}\text { Security } \\
\text { concerns/privacy fears }\end{array}$ & 12 & $\begin{array}{c}2.6 \\
7 \\
\end{array}$ & $\begin{array}{c}1.15 \\
5 \\
\end{array}$ & $\begin{array}{c}1.6 \\
7 \\
\end{array}$ & .651 & 2.83 & 1.193 \\
\hline $\begin{array}{c}\text { High rate of } \\
\text { obsolescence ICT } \\
\text { products in the } \\
\text { Ghanaian market }\end{array}$ & 12 & $\begin{array}{c}3.2 \\
5\end{array}$ & $\begin{array}{c}1.05 \\
5\end{array}$ & $\begin{array}{c}2.0 \\
0\end{array}$ & .739 & 2.75 & 1.138 \\
\hline $\begin{array}{l}\text { Access to relatively } \\
\text { cheap work force }\end{array}$ & 12 & $\begin{array}{c}2.6 \\
7\end{array}$ & $\begin{array}{c}1.07 \\
3\end{array}$ & $\begin{array}{c}2.1 \\
7\end{array}$ & .937 & 2.25 & 1.215 \\
\hline $\begin{array}{l}\text { Majority of clients not } \\
\text { interested in the library } \\
\text { ICT base }\end{array}$ & 12 & $\begin{array}{c}2.9 \\
2\end{array}$ & $\begin{array}{c}1.24 \\
0\end{array}$ & $\begin{array}{c}2.5 \\
0\end{array}$ & $\begin{array}{c}1.18 \\
7\end{array}$ & 2.17 & 1.115 \\
\hline $\begin{array}{c}\text { Erratic supply of } \\
\text { electricity }\end{array}$ & 12 & $\begin{array}{c}3.5 \\
0\end{array}$ & $\begin{array}{c}1.38 \\
2\end{array}$ & $\begin{array}{c}3.5 \\
8\end{array}$ & $\begin{array}{c}1.31 \\
1\end{array}$ & 3.08 & .996 \\
\hline Risk for liability & 12 & $\begin{array}{c}2.4 \\
2\end{array}$ & $\begin{array}{c}1.08 \\
4\end{array}$ & $\begin{array}{c}1.8 \\
3\end{array}$ & .937 & 2.33 & .888 \\
\hline $\begin{array}{c}\text { Inadequate legal } \\
\text { support for use of ICT }\end{array}$ & 12 & $\begin{array}{c}2.5 \\
8\end{array}$ & .900 & $\begin{array}{c}2.0 \\
0\end{array}$ & $\begin{array}{c}1.20 \\
6\end{array}$ & 1.58 & .900 \\
\hline $\begin{array}{l}\text { Security implication of } \\
\text { transactions }\end{array}$ & 12 & $\begin{array}{c}2.4 \\
2\end{array}$ & .900 & $\begin{array}{c}1.7 \\
5\end{array}$ & .965 & 1.50 & .798 \\
\hline
\end{tabular}

Source: Field Survey

\section{Factors hindering the use and adoption ICT in Polytechnics}

Inadequate commitment by tertiary institutions management towards ICT, Fear of job losses/making professionals redundant, Satisfaction with existing methods of work, Budget constraints for ICT investment, High cost of employing ICT professionals in their library and Erratic supply of electricity were identified by respondents from the Polytechnic category (From Table 10) as the main factors affecting the adoption and use of ICT in their libraries. Security concerns/privacy issues and limited benefits/low return on investment in ICT were identified as the least factor.

Table 11: Challenges hindering the adoption and usage of ICT resources by Polytechnics in Ghana

\begin{tabular}{|c|c|c|c|c|c|}
\hline \multirow{2}{*}{ Factors } & \multirow[b]{2}{*}{$\mathrm{N}$} & \multicolumn{2}{|c|}{ T-Poly } & \multicolumn{2}{|c|}{ Wa - Poly } \\
\hline & & Mean & SD & Mean & SD \\
\hline $\begin{array}{c}\text { Budget constraints for ICT } \\
\text { investment. }\end{array}$ & 12 & 2.58 & 1.621 & 4.08 & .900 \\
\hline $\begin{array}{l}\text { Cost of training professionals in } \\
\text { ICT }\end{array}$ & 12 & 2.42 & 1.240 & 2.08 & 1.240 \\
\hline $\begin{array}{l}\text { Limited benefits/ low return on } \\
\text { investment in ICT }\end{array}$ & 12 & 1.58 & .793 & 2.83 & 1.403 \\
\hline $\begin{array}{l}\text { High cost of employing ICT } \\
\text { professional }\end{array}$ & 12 & 1.75 & .965 & 3.00 & 1.595 \\
\hline $\begin{array}{l}\text { Inadequate commitment by } \\
\text { tertiary institutions' management } \\
\text { towards ICT }\end{array}$ & 12 & 3.42 & 1.379 & 3.75 & 1.357 \\
\hline $\begin{array}{l}\text { Inadequate knowledge about the } \\
\text { return on ICT investment }\end{array}$ & 12 & 2.17 & 1.115 & 2.08 & 1.084 \\
\hline $\begin{array}{l}\text { Lack of staff with appropriate skill } \\
\text { and knowledge in ICT }\end{array}$ & 12 & 2.58 & 1.564 & 2.42 & 1.443 \\
\hline $\begin{array}{l}\text { Fear of job losses/making } \\
\text { professionals redundant }\end{array}$ & 12 & 3.08 & 1.505 & 1.83 & 1.267 \\
\hline $\begin{array}{l}\text { Satisfaction with existing methods } \\
\text { of work }\end{array}$ & 12 & 3.50 & 1.314 & 2.75 & 1.122 \\
\hline $\begin{array}{l}\text { Rapid changes in ICT } \\
\text { technologies }\end{array}$ & 12 & 2.00 & 1.348 & 2.17 & 1.337 \\
\hline $\begin{array}{l}\text { Problems of ICT integration } \\
\text { /compatibility in the library }\end{array}$ & 12 & 2.42 & 1.311 & 2.42 & 1.505 \\
\hline $\begin{array}{l}\text { Software and hardware reliability } \\
\text { problems }\end{array}$ & 12 & 2.00 & .953 & 1.83 & 1.193 \\
\hline Security concerns/privacy fears & 12 & 2.33 & 1.155 & 1.67 & 1.231 \\
\hline $\begin{array}{l}\text { High rate of obsolescence ICT } \\
\text { products in the Ghanaian market }\end{array}$ & 12 & 2.08 & 1.165 & 2.25 & 1.485 \\
\hline $\begin{array}{l}\text { Access to relatively cheap work } \\
\text { force }\end{array}$ & 12 & 2.92 & 1.311 & 2.08 & 1.084 \\
\hline $\begin{array}{l}\text { Majority of clients not interested } \\
\text { in the library ICT base }\end{array}$ & 12 & 1.75 & 1.055 & 2.08 & 1.165 \\
\hline Erratic supply of electricity & 12 & 2.67 & 1.557 & 3.00 & 1.128 \\
\hline Risk for liability & 12 & 2.08 & 1.379 & 1.92 & 1.165 \\
\hline $\begin{array}{l}\text { Inadequate legal support for use of } \\
\text { ICT }\end{array}$ & 12 & 1.83 & 1.030 & 2.08 & 1.165 \\
\hline $\begin{array}{l}\text { Security implication of } \\
\text { transactions }\end{array}$ & 12 & 2.42 & 1.240 & 2.00 & 1.348 \\
\hline
\end{tabular}

Source: Field Survey

Comparison of factors identified as important hindrance to ICT adoption and use

The essence of the categorization was to compare respondent's institutions. This was done to identify challenges 
that are unique in institutions as well as those that seem to be common among the institutions.

Results (Table 11) indicates that Budget constraints for ICT investment, Inadequate commitment by tertiary institutions management towards ICT and erratic supply of electricity run through all categories as factors hindering ICT adoption and use, Satisfaction with existing methods of work is the common factor that affects both the Polytechnics and Colleges while high cost of employing ICT professionals was a common thing that affects both the University and Polytechnic categories. Factors such as Problems of ICT integration/compatibility in the library, High rate of obsolescence of ICT products in Ghanaian market, Lack of staff with appropriate skills and knowledge in ICT and Rapid changes in ICTs were unique factors associated with the college category, with Fear of job losses/ making professionals redundant identified as a unique factor affecting the Polytechnic category.

Three key factors namely Budget constraints for ICT investment, inadequate commitment by tertiary institutions management towards ICTs and erratic electricity supply were identified as a common factor across all categories and ranked as tops by respondents in factors affecting the availability and use of ICTs in libraries

Table 12: Comparison of factors identified as important hindrance to ICT adoption and use

\begin{tabular}{|c|c|}
\hline Category & Factors Identified \\
\hline Universities & $\begin{array}{l}\text { Budget constraints for ICT investment } \\
\text { Inadequate commitment by tertiary institutions } \\
\text { management towards ICT } \\
\text { Erratic supply of electricity } \\
\text { High cost of employing ICT professionals in their library }\end{array}$ \\
\hline Polytechnics & $\begin{array}{l}\text { Inadequate commitment by tertiary institutions } \\
\text { management towards ICT } \\
\text { Fear of job losses/making professionals redundant } \\
\text { Satisfaction with existing methods of work } \\
\text { Budget constraints for ICT investment } \\
\text { High cost of employing ICT professionals in their library } \\
\text { Erratic supply of electricity }\end{array}$ \\
\hline Colleges & $\begin{array}{l}\text { Inadequate commitment by tertiary institutions } \\
\text { management towards ICT } \\
\text { Erratic supply of electricity } \\
\text { Budget constraints for ICT investment } \\
\text { Satisfaction with existing methods of work } \\
\text { Problems of ICT integration/compatibility in the library } \\
\text { High rate of obsolescence of ICT products in Ghanaian } \\
\text { market } \\
\text { Lack of staff with appropriate skills and knowledge in ICT } \\
\text { Rapid changes in ICT technologies }\end{array}$ \\
\hline
\end{tabular}

Source: Field Survey

\section{CONCLUSIONS}

Despite the many challenges of Ghanaian libraries, Information and Communication Technology (ICT) is well recognized by them as a significant technological system that can help increase the effectiveness and efficiency of library operations to meet user needs. The study revealed that there is a significant level of awareness among respondents about the benefits ICT could offer to library operations. Also the use of selected hardware particularly desktop PC and Laptops appear to be high.

It is observed that the current level of ICT usage in academic libraries in Ghana in general appear to be at the rudimentary stage consisting of basic software and hardware usage. In spite of the fact that more advanced ICT applications seem to be inadequate in the libraries, most of the libraries using ICT perceive their current usage as average. On the other hand, most of the libraries in the southern sector used ICT more in operating their libraries, those of the libraries in the northern sector was woefully low.

It is notable that, the most significant factors affecting the adoption and use of ICT by the libraries were budget constraints, inadequate commitment by their institutions' management and erratic supply of electricity. These factors explain why the present levels of ICT usage among the institutional libraries in Ghana is generally low. Whilst the attitude and interest of academic institutions in Ghana seem promising towards ICT usage, the factors identified continue to be the major issues that the institutions, stakeholders, shareholders and other donor organization's need to address in order to increase adoption and usage of ICT in academic institutions for their libraries to drive the full benefits and meet user needs.

Finally, it is gratifying that ICT has come to stay and has achieved remarkable level of usage in the libraries of Kwame Nkrumah University of Science and Technology, University of Ghana and Kumasi Nursing and Midwifery Training College.

\section{VI.RECOMMENDATIONS}

Following on the findings of the study, the following recommendations have been proposed:

Financial support should be provided to develop the basic ICT infrastructure of the libraries. Investing in ICT should no longer be primarily buying a piece of hardware and software; it should be more of a long term investment in the process of change. Due to the low funding of academic libraries as discovered in this study, there is the need for the government to support the institutional libraries and internal policies made towards investing in ICT in the libraries. The institutions themselves should be motivated by the benefits of ICT and increase their budgetary allocations for their libraries towards ICT development, since that will enhance the quality and effectiveness of the institutions research. The assistants of donor agencies such as GETFUND and other NonGovernment Agencies should come to the aid of tertiary libraries by providing financial aid and supporting the libraries with ICT equipment to meet user needs.

The management of libraries is rapidly moving away from the traditional paper- based formats towards a more digital one. Therefore management of the institutions' must provide effective leadership towards the successful implementation of 
ICT in their academic libraries. This will require will power, motivation and strategic planning towards creating the required enabling environment for ICT development. The institutions should also be committed to devising strategies for generating funds internally.

Efforts should be towards addressing erratic power supply to enable continuous usage of ICT facilities in institutional libraries. Also, effective and efficient power supply supplements such as standby generators should be provided to check the menace of frequent power outages.

\section{REFERENCES}

[1] Abels, E. (2003). Competencies for information professionals of the 21st century. Retrieved August 12, 2009, from Special Libraries www.sla.org/content/learn/comp2003/index.cfm 2 .

[2] Alemna,A.A, Ksiedu . C. O and AntwiI.K. (1996). Library facilities in polytechnics of Ghana in view of their new role as tertiary institutions: Aslib proceedings, Vol.48, no10.

[3] Academic Library (2010), February 15). Wikipedia. Retrieved February 15, 2010.

[4] Adeniran, P. (2011). User satisfaction with academic library services: Academic staff and students' perspectives. International Journal of Library and Information Science. Vol.3 (10), 209-216.

[5] Adetona, C. O. (2010). Resources utilization in public libraries in Nigeria: the case of Ibusa and Issele-Uku branch libraries users in Delta State. International Journal of Research in Education vol.7 (2) $1-10$.

[6] Afolabi, A, F and Abidoye, J.A (2011). Integration of Information and Communication Technology in library operations towards effective library services. Proceeding of 1st International technology, education and environment conference (C) Africa Society for Scientific Research (ASSR).

[7] Aguolu. I. E. (1996). Nigerian University Libraries: What Future? The International Information and Library Review, 28(3), 261.

[8] Agyen-Gyasi, K, Lamptey, R. and Frempong, A. (2010). Academic librarians' role in maximizing library use in Ghana. dspace.knust.edu.gh:8080/ [accessed: December 17, 2012].

[9] Aina, L. O. (2004). Library and information science text for Africa. Ibadan: Third World Information Services.

[10] Ajayi, G. O. (2002). Information age virtual technologyopportunities and challenges to Africa. Paper presented at: UNESCO National Workshop on the Pilot Virtual University Laboratory Project, the Obafemi Awolowo University, Ile-Ife A, 9-12 September.

[11] Amarjeet Kaur Bhangu (2013). Use of ICT in academic libraries. International journal of scientific Engineering and technology volume No. 2, issue No. 11pp: 1162-1167.

[12] Anyim, W. O., (2018). E-Library Resources and Services: Improvement and Innovation of Access and Retrieval for Effective Research Activities in University E-libraries in Kogi State Nigeria. Library Philosophy and Practice (e-journal). 1647. https://digitalcommons.unl.edu/libphilprac/1647

[13] Banting, G. et al (2008).Ensuring bright future for research libraries: A guide for vice-chancellors and senior institutional managers. www.rin.ac.uk./bright-future-libraries [accessed: November 13, 2012].

[14] Blurton, C. (1999). New Directions of ICT-Use in Education. World Communication and Information Report. UNESCO.

[15] Bozimo, D.O (1983). Nigerian universities li brary needs od academics as basis for co-operative planning. Journal of librarianship 15 (2): 123-125

[16] Branscomb, L.M., (1981). In: Nasiruddin, M., (2001). Information Infrastructure in Balangladesh: Need for a National Approach, Rajshahi University studies, Part-C, 9:45.

[17] Brown, C. M. (2007). The university librarian, the key to every university's success. Daily Graphic. Thursday, November 15.
[18] Bryman, A. (2008) Social Research Methods, 3rd edition, Oxford University Press Inc., New York.

[19] Buckland, M (1992). Resdesigning library services: A manifesto. Chicago: ALA Books.

[20] Capron, H. L. (2000). Computers: Tools for an Information Age. New Jersey: Prentice Hall.

[21] Chalukya B.V.,"Academic Libraries and User Education" eLibrary Science Research Journal, Volume 3, Issue 5, March 2015 , Online \& Print.

[22] Chasenga, J, (2004). ICT in Libraries: An overview and general introduction to ICT in Libraries in Africa. Paper presented at INASP ICT workshop, held at Johannesburg, South Africa.

[23] Chisenga, J. (1995). The Skills of Information Technology in Zambian Libraries.

[24] Chisenga, J. (2004).The Use of ICTs in African Public Libraries: A Survey of Ten Countries in Anglophone Africa. Oxford: International network for the availability of Scientific Publications (INASP)

[25] Communication Media and Electronic Revolution, (1996). Aruna Zacharia (ED), New Delhi: Kaniska Publishers, pp: 66.

[26] Creswell, J.W \& Tashakkori, A (2007), Editorial: differing perspectives on mixed methods manuscripts. Journal of mixed research, 1 2: 107-111.

[27] Creswell, J.W \&Garret, A.L (20085). The movement of mixed methods research and the role of educator. South African journal of education, 28:321-333.

[28] Curzon, Susan; Jennie Quinonez-Skinner $(9$ September 2009). Academic Libraries. Encyclopedia of Library and Information Sciences. pp. 11-22. doi:10.1081/E-ELIS3120044525. ISBN 978-0-8493-9712-7. September 2013.

[29] Daniel, J. O. (2000). Virtual Library for Nigerian Libraries. Nigerian Libraries, 36(2), 56.

[30] David, T. L. (2001). ICT for Library and Information Professionals: A Training Package for Developing Countries (ICTLIP). Retrieved June 26, 2009, from e-Library Download Page: index.htm

[31] Dike, V. (2005). More than Computers Information Technology in Library and Information Service Education, Ibadan: NALISE 5059.

[32] Doherty J. M. (1997). "A Survey of Computer Use in the New Zealand Building and Construction Industry" Electronic Journal of Information Technology in Construction - ITCon Vol 2 (http://www./itcon.org/1997/).

[33] Dunmill, M. and Arslangaic, A. (2006). ICT in Arts Education. Literature Review. New Zealand, University of Canterbury.

[34] Evans. G. E., Amodeo, A. J and Carter, T. L. (1999). Introduction to library public services (6th edn.). Colorado: Libraries Unlimited.

[35] Ezeani, Chinwe Nwogo and Igwesi, uzoamaka, (2012). "Using Social Madia for Dynamic Library Service Delivery: The Nigeria Experience" Library Philosophy and practice (e-journal). Paper 814.

[36] Farag et.al, (2009). Usage of Information Technology in construction firms; Malaysian Construction Induatry. European journal of scientific research, Vol. 28 No3, pp 412-429.

[37] Feldman, Robert S. (2000). P.O.W.E.R. learning: strategies for success in college and life. Boston, IL: McGraw- Hill.

[38] Field, B and Ofori, G (1988).Construction and Economic Development - a case study. Third World Planning Review, 10(1), 41-50 Flowers (1996).Using computer technology on site - the advantages, 2(8).

[39] Gallimore, A. (1996). A public library IT strategy for the millennium. Journal of Librarianship and Information Science. Vol. 28 No. 3, 149-57.

[40] Gardner, B. (1994). Ensuring Successful Information Technology Utilization in Developing Countries. Garborone: Botswana (Pty) Limited, Botswana, 12-20.

[41] GNA story (2011). (http: www.ghana news agency.org/features/education -sector-dev't-key-to-successful-poverty intervention-in- 
three-northern-region--32070) Published: 2011-08-08 21:37:93 @) Ghana News Agency.

[42] Goswami, P. R. (2009). Academic librarianship in india: exploring strategic intent and core competencies in the present era. Retrieved June 7, 2010, from International Conference on Academic Libraries ICADL 2009: http://crl.du.ac.in/ical09/papers /index_files/ical-57_148_324_2_RV.pdf

[43] Haliso, Y. (2007). Internet availability and use in academic libraries in south west Nigeria. Babcock Journal of Management and Social Science, Vol.5 No.2.January 2007 Special Edition.pp:246-261.

[44] Hamelink, C, J. (1997). New Information and Communication technologies: Development and Cultural changes.

[45] Harrison, C. and Beenham, R. (1985).The basics of librarianship. (2nd edn) London: Clive Bingley Limited.

[46] Hussaini S., Haruna M., Muhammad A., (2021), Application and Use of ICT in University Library Services: A Panacea for Conventional Library Services. Journal of Information Technology and Sciences. Vol-7, Issue-1 (January-April, 2021). Doi.org/10.46610/JOTS.2021.v07i01.001

[47] Husain, S.,Nazim, M. (2015). Use of different information and communication technologies in Indian academic libraries. Library review, 64 (1/2), 135-153. https;//doi.org/108/LR-06-2014-0070.

[48] Idowu, A. O. (2011). Effective Library Services in the College, A paper deliver at the 1st Library Workshop at Adeyemi College of Education, Ondo.

[49] Igbeka (2008), Adebisi (2009) and Uwaifor (2010). Enumerated the Impact of Information and Communication Technology (ICT) in Library Operations and Services thus: from pp. 2-8.

[50] Islam, M. S, and Islam, M. N. (2007). Use of ICT in Libraries: An Empirical Study of Selected Libraries in Bangladesh. Library Philosophy and Practice, available at http: //todde.anadolu.edu.tr/tojde21/articles/islam.htm, accessed June 2010.

[51] Issele-Uku branch libraries users in Delta State. International Journal of Research in Education vol.7 (2) 1-10.

[52] Khan J., (2016), "impact of information communication technology on library and its services" International Journal of Research - Granthaalayah, Vol. 4, No. 9 (2016): 97-100.

[53] Kawatra, P. S. (2000). 2000 Plus: Library and information systems in the 21st century. New Delhi: Crest Publishing House.

[54] Krasner-Khait, B. (2001). Survivor: the history of the library. www.history-magazine.com/libraries.html. [Accessed: April 18, 2009].

[55] Kumar, K. (1987). Library administration and management. New Delhi: Vikas Publishing House Pvt Ltd.

[56] Kumar, P. S. (2003). Information Technology: Basics. New Delhi: B R Publishing Corporation.

[57] Lesikar, R.V. and Petit, J. D. (1995). Report writing for business.(9th edn.). Chicago: Irwin.

[58] Md. Shariful Islam and Md. Nazmul Islam, (2006). Information and Communication Technology (ICT) in libraries: A New Dimension in librarianship. A sign journal of information technology 5(8): 809-817, 2006@medwell, 2006.

[59] Nwankwo. A.N. (2006). The Need for ICT Education for Effective Library Work and Services, paper presented at the 2006 Department of Library and Information Science Seminar, 5th 10th February.
[60] Ogunsola L.A (2004). Nigeria University libraries and the challenges of globalization: The way forward.V.5 no 2-3 (Fall 2004).

[61] Okiy, R.B.(2005). Strengthening Information Provision in Nigerian university Libraries through Information communication technologies. The Electronic Library 23.3: 311-318.

[62] Onohwakpor, J.E. (2006). The Role of Library in the Sustenance Functional Library and Community Development. International Journal of Research in Education 3(1) 60-64.

[63] Osundina, O. (1973). The Relationship between Information Science and Librarianship: a viewpoint. Nigerian Libraries, $9(1 \& 2), 47$.

[64] Patil, D.B., S.S Kumbarand and H. Krishnananda, (1994). Information Technology: Current Trends In; Patil,D.B. and Kooganuramath, M.M. Library and Information Science, New Delhi: Ashis Publishing, pp:33.

[65] Peyala, V. (2011). Impact of using information technology in central university libraries in India: Results of a survey. Program, 45(3), 308-322. https://doi.org/10.1108/00330331111151610

[66] Rahaman, L., (2003). Global Context of ICT Development and Bangladesh, The Proceeding of the National Conference of Interuniversity IT Professional in Bangladesh, pp:1-22.

[67] Rana, H.K. (2009). Impact of Information and Communication Technology on Academic Libraries in Punjab.

[68] Rowley, J, E. and P. Lea, (1987). Info Tech: A Guide for Young Professional Libraries, London: Remploy Ltd, pp: 3-5.

[69] Savio, R. (1990). Communication for development. Development Journal, 2, 7-8.

[70] Shaping the future:ASERL's competencies for research librarians. Retrieved August 12, 2009, from ASERL: http://www.aserl.org/statements/competencies/ competencies.htm

[71] Shukla, Akhandanand, and Sialai, S. (2016). Information Communication Technology application in academic libraries. In Maurya, R.J. (Ed) "Future of academic libraries: Issues and challenges (pp.62-72). New Delhi: pentagon Press for (UPRTOU, ATLAHABAD)

[72] Shuva, N.Z. (2005). Implementing information and communication technology in public libraries in Bangladesh. The International Information and Library Review, 37,159-168.

[73] Stephen, G (2017) Utilization of ICT based resources and services in engineering college libraries case study of Sivagangai and Ramanathapuram Districts. Retrieved from: http://hdl.handle.net/10603/184724

[74] The Association of College and Research Libraries (ACRL). (2010, February 26,). Retrieved February 26, 2010 website.

[75] Tristnikov, V. N. (1970). Information. In Great Soviet Encyclopedia (Vol. 10, p. 274). New York: Macmillan.

[76] Ubogu, J. O. and Okiy, R. B (2007). Sources of funds in academic libraries in Delta State, Nigeria. Library Philosophy and Practicehttp: //unlib.unl.edu/LPP/ [accessed: December 12, 2012].

[77] Ugwuanyi, C. F., Okwor, R. N. and Ezeji, E. C (2011). "Library space and place: nature, use and impact on academic library". International Journal of Library and Information Science vol.3 (5), 92-97.

[78] Whittaker, K. (1993). The basics of library-based user services. London: Library Association Publishing.

[79] Wolpert, A. (1999). Services to Remote Users: Marketing the Library's Role. Library Trends 47.1:34.

[80] Youngman, D. (1999). Library Staffing Considerations in the Age of Technology. Basic Elements for Managing Change. 